\title{
Gwynedd Mercy University's ABD Completion Program for Doctoral-non-completer-students Who Wish to Complete their Ed.D.
}

\author{
Tamara Bell Boyle \\ University of Wilmington, USA
}

\begin{abstract}
One of the major goals pursued by the author of this study is to give hope to doctoral-non-completerstudents who wish to earn their Doctorate in Education (Ed.D.). The other major goal is to provide insight to instructors and institutions about why a doctoral student might leave a program whilst guiding the instructors and institutions about the factors doctoral-non-completer-students need to complete their Ed.D. degree. This research will examine the principal factors that influenced doctoral-non-completer-students to leave their original doctoral program without completing and the principal factors that influenced these prior doctoral-non-completer-students to complete their degree requirements in a different university's doctoral program (i.e., Gwynedd Mercy University (GMercyU.edu) All But Dissertation (ABD) Completion Program). The research findings of this study identify employment and financial factors as the principal reasons for non-completion. The main reason Participant A completed the ABD Completion Program at GMercyU was because the on-line courses were highly flexible. Whereas Participant B was able to restructure his life (i.e., retire) and Participant $C$ was in a different financial situation. All the Figures in this paper are gathered during indepth interviews with research participants.
\end{abstract}

Keywords: All But Dissertation (ABD) Completion Program, simultaneous doctoral course sequence, doctoral-non-completer-students

\section{Introduction}

Abiddin et al. [1] referenced Lovitts et al. [2] found one-third leave in first year of their doctoral studies in the United States (U.S.). Thus, approximately $33 \%$ doctoral students leave their programs in what is known as Stage 1. In Leaving the Ivory Tower the Causes and Consequences of Departure from Doctoral Study by Lovitts [3] it was referenced that a "total first-year attrition for noncompleters to 35 percent" (as cited in Bowen et al. [4]). In addition, "between 15 and 25 percent of graduate students who advance to candidacy for the Ph.D. (Stage 3) never complete" [3]. Cassuto [5] found U.S. math and science doctoral students who exit usually do so before year three. In addition, 50\% of doctoral humanities students exit before year three; whereas $25 \%$ of the remainder of the doctoral humanities students exit before the seventh year, which is known as the "trickle out" effect [5]. As just illustrated, completion rate of doctoral students is ambiguous. There is a huge variance (i.e., 66\%) between the highest and the lowest completion rate percent. Macleod [6] found United Kingdom (U.K.) doctoral agriculture completion rate at $76 \%$; whereas, Cassuto [5] found a ten percent completion rate for English doctoral students in the U.S. Why are some doctoral students completing whilst others are not?

Some non-completers have the desire and energy to complete their doctoral degree but are faced with different barriers. Lovitts [3] believes doctoral attrition rate is invisible to higher education institution's staff because of the way doctoral education is structured and how the doctoral student/non-completer depart from the higher education institution. Willis et al. [7] highlighted two barriers (i.e., problematic chair relationship and career as refuge) non-completers identified. However, Rockinson-Szapkiw et al. [8] found 12 factors on "both the student level and the institutional level that contribute to students' choice to leave doctoral programs" [8]. In addition, Rockinson-Szapkiw et al. [8] also found six factors doctoral students need to be successful and complete their work on the degree.

In 2016, at the start of this research there was only one All But Dissertation Completion Program (ABD completion program) in the U.S. The ABD Completion Program is a Doctor of Education (Ed.D.) program designed by and offered at Gwynedd Mercy University (GMercyU), which allows doctoral-non-completer-students to earn their EdD. This research tests Rockinson-Szapkiw et al. [8] 12 and six factors by investigating two questions:

(1) What are the principal factors that influenced doctoral-non-completer-students to leave their original doctoral program without completing the degree? 
(2) What are the principal factors that influenced these prior doctoral-non-completer-students to actually complete their degree requirements in a different university's doctoral program?

\section{Population and Institutions}

Three case studies were adopted as evidence base. The ABD Completion Program at GMercyU was in its infancy at the start of this research and the total population pool for this research was eight. The three participants each attended different original doctoral institutions, which will be known as Institution $\mathrm{A}$, Institution $\mathrm{B}$, and Institution $\mathrm{C}$. Participant \#1 and Participant \#3's original programs were in-person. Whereas Participant \#2's original program was mostly face to face with a "couple of online courses". All participants' original programs were part-time, while they were employed full-time. Participant \#1 and Participant \#3 were married while attending their original programs. Whereas, Participant \#2 was single while attending their original program. In addition, all of the participants were self-funded during their original program. Two out of the three participants completed all their course work up to the dissertation. The other participant "stopped going after about five classes".

All three participants attended the ABD Completion program at GMercyU. Each doctoralnon-completer-student's transcript were evaluated in order for the program director at GMercyU to create an individual learning plan for each of the doctoralnon-completer-students. The doctoral-noncompleter-student is able to select from three different concentrations (i.e., K-12, Special Education, and Higher Education) for the program. The program was offered online and was accelerated. In addition, students were continuously working on their dissertation with their dissertation chair after starting the program. Thus, GMercyU utilizes a simultaneous doctoral course sequence, which includes a dissertation course-structure (i.e., four dissertation advisement courses). The Figure 1 is an example of the possible required courses, for the Online Accelerated ABD Completion Program in Education with Concentration in Higher Education. It is impossible to provide the actual required courses, because each doctoral-non-completerstudent's transcript were evaluated to create their individual learning plan.

The ABD Completion program was full-time and designed for students who are full-time employed. However, Participant $\mathrm{A}$ and Participant $\mathrm{C}$ were employed full-time and Participant B was employed part-time during the ABD Completion Program. In addition, Participant A was married while attending the ABD Completion Program. Whereas Participant $\mathrm{B}$ was single while attending the ABD Completion Program. In addition, Participant $\mathrm{C}$ was divorced while attending the ABD Completion Program. Furthermore, all of the participants were self-funded during the ABD Completion Program. Lastly, all participants were males, because no females responded to being a participant.

\begin{tabular}{|c|c|}
\hline Courses: & Additional Work: \\
\hline Online Readiness Course & \\
\hline $\begin{array}{l}\text { Ed Policy and Practice in } \\
\text { U.S. Residency }\end{array}$ & \multirow[t]{9}{*}{$\begin{array}{c}\text { Working on Dissertation } \\
\text { with Dissertation Chair }\end{array}$} \\
\hline Dissertation Advisement I & \\
\hline $\begin{array}{l}\text { Ethics in Ed Leadership } \\
\text { Residency }\end{array}$ & \\
\hline Dissertation Advisement II & \\
\hline Advance Statistics & \\
\hline Global Ed Policy Residency & \\
\hline Dissertation Advisement III & \\
\hline $\begin{array}{l}\text { Equity, Equality, and Equal } \\
\text { Opportunity }\end{array}$ & \\
\hline Dissertation Advisement IV & \\
\hline
\end{tabular}

Figure 1. Example of Possible Required Courses for the ABD Completion Program in Education with Concentration in Higher Education

\section{Importance of this Study}

Doctoral students who do not complete their degree impact society, institutions, and themselves. Society is impacted because there are less educated people. Thus, less advancement in science, medicine, and engineering fields [9]. The higher education institution loses monetary value. Professors provide one-on-one instructions to doctoral students; some doctoral students receive specialized equipment supplied by the higher education institution; and some doctoral students are graduate research assistants and teaching assistants [10]. Lovitts [3] and Rockinson-Szapkiw et al. [8] believes the most important reason to be concerned about a low doctoral graduation rate is that not graduating can ruin the non-completer's life. The non-completer will have massive financial, personal, and professional cost by not completing their doctoral degree [3]. Cassuto [5] found students that do not complete their doctoral degrees carry a larger student-loan debt than those who complete their degrees, possibly because the student will lose out because some noncompleters will take blue collar positions after leaving their graduate schools [3]. "Students who start college but do not graduate are stuck with loan repayments and no college degree. ... Many students who are defaulting on loans fall into this category" [11]. According to Cooper [12] non-completers are less motivated to pay back their student loans. Freedman [11] found individuals with student loan debt are less likely to purchase homes and cars. Therefore, one could argue, doctoral student noncompletion could impact student loan debt, and student loan debt could impact the economy because 
the former students cannot put money back into economy/society. Thus, the circle continues with the economy/society being further impacted, by the noncompleter if they do not pay their student loans. Image 1, Impact from a Low Student Completion Rate, illustrates the impact circle of a non-completer.

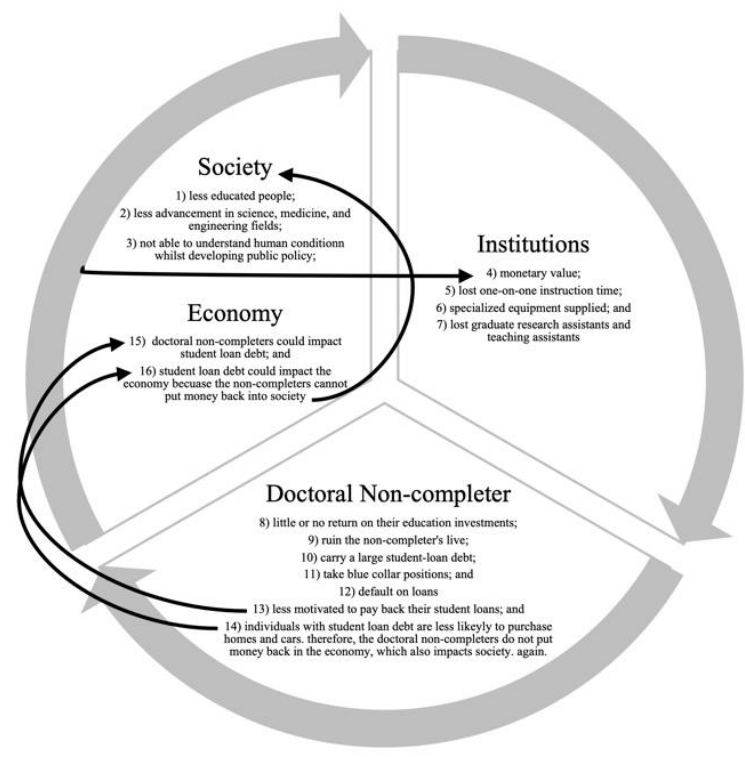

Image 1. Impact from a Low Student Completion Rate

\section{Literature Review}

The highest level of education, in most fields [13] [14] is the doctoral program [10] and the student earns, what is known in the U.S., a 'terminal degree' [13]. A 'terminal degree' prepares the graduate to be a practitioner within the discipline that they earned their degree [15]. Both a Doctor of Philosophy Degree (Ph.D.) and Doctor of Education Degree (Ed.D.) are two types of terminal degrees a student can earn after completing a doctoral program. A traditional Ph.D. program centers around a doctoral student finding a gap in the literature and then creates new knowledge to fill the gap [15]. Whereas an Ed.D. program revolves around action research and preparing the student, with a hands-on approach, for a leadership/administrative role within a particular field [15]. "Doctoral degrees can only be awarded by universities" [16].

According to Graduate School Initiatives in Doctoral Education and Student Support Brown University has expanded their student development to "foster research, teaching, and professional development skills" in their graduate school [17]. In addition, Nova Southeastern University Florida designed their Doctor of Education in Higher Education Leadership "specifically for practicing and aspiring educators, trainers, and staff developers working with adult learners"; so that their graduates can "serve as leaders in improving the academic and administrative performance of colleges and universities" [18]. Thus, one could argue, doctoral students are being prepared to be lifetime learners. Bates [19] emphasizes completing a doctoral degree is an extremely slow process.

According to MacLeod [6] after seven years, three out of ten full-time students pursuing a doctoral degree, in the U.K., still have not completed their degree. MacLeod [6] found doctoral students in natural sciences and maths had a higher completion rate compared to their peers in the humanities and social sciences in the U.K.. "Agriculture [natural sciences] came top of the doctorates league, with $76 \%$ of students completing the course, compared to an overall average of $62 \%$ " [6]. In addition, only $33 \%$ of part-time doctoral student submit a doctoral thesis (i.e., dissertation) [6]. This illustrates a $29 \%$ variance between the overall average and those who submit their doctoral thesis (i.e., dissertation). Kehm [16] found in Germany that there are no statistics, but drop-out is frequent. Doctoral completion rate is varying between subjects; however, the average is between four and six years. In Ph.D. Degree Completion in Canadian Universities: Final Report by Frank Elgar [20] found Canada's doctoral completion rate in life sciences was $70.4 \%$, in natural and applied sciences was $66.7 \%$, and social sciences were $48.5 \%$, and arts and humanities was $44.7 \%$. Whereas, a 2001 paper predicted $60 \%$ of Australian doctoral students who started in 1992 will successfully complete their program by $2003-11$ years after starting [1]. According to Cassuto [5] in 1961, the University of California at Berkeley had a cohort of 120 new graduate students in the graduate school in English. However, only 12 earned their Ph.D.'s. Thus, only ten percent of the doctoral students completed their degree. Furthermore, differences between full-time and part-time students were noted; full-time $\mathrm{PhD}$ students in Computing had a $50 \%$ completion rate, but part-time students only had $23 \%$ [6]. Therefore, status (i.e., full-time versus part-time) is also another factor in doctoral completion rates. In addition, MacLeod [6] found doctoral students with "financial backing, particularly from research councils, charities or the British Academy" were more successful at completing their degrees compared to those doctoral students without financial backing. As illustrated with the prior information, there is ambiguity and a $66 \%$ variance between the highest (i.e., 76\% [6]) and the lowest (i.e., ten percent [5]) doctoral completion rate.

Patterson [21], Cassuto [5], Chenevix-Trench [22] and D'Andrea [10] perceive the students themselves were the cause of the low doctoral student completion rate. 


\section{Why Do So Many Graduate Students Quit?}

Universities Themselves May be Contributing to Burnout by Patterson [21] found some doctoral students burn out and offered the following explanation:

Mental illness is often offered as the standard rationale to explain why some graduate students burn out. Some research has suggested a link between intelligence and conditions such as bipolar disorder, leading some observers to believe many graduate students struggle with mental-health problems that predispose them to burning out [21].

Cassuto [5] places doctoral candidates into three categories: "Those who can't get it done. ... Those who have the ability to finish but choose not to. ... [and] Everyone else- that is, those who complete their doctorates." In What Makes a Good PhD Student? by Chenevix-Trench [22] believes most new doctoral students are "ill-prepared" because grade inflation makes it difficult to identify great doctoral candidates from ok candidates. In addition, D'Andrea [10] researched obstacles that prevented doctoral students from completing their degree. The findings were doctoral students had "difficult with planning and writing, working independently, and financial and personal-relationship pressures" [10]. Thus, one could argue, the 2 factors D'Andrea [10] presented is (1) doctoral students are not academically prepared and (2) pressures (i.e., financial and personal-relationship). However, other authors (see Lovitts [23]; Lovitts [3]; Bates [19]; MacLeod [6]; Abiddin et al. [1]) believe low doctoral student completion rate could stem from the student's background characteristics (i.e., gender, first generation student, age, student status, prior GPA, employment status, financial status, marital status, and race and ethnicity). In The Transition to Independent Research: Who Makes It, Who Doesn't, and Why by Lovitts [23] investigates her research questions from a theoretical perspective and practical observation from "high-PhD-productive faculty" [23]. Lovitts [23] analysis emphasizes that characteristics can and do impact a student's outcome (i.e., completing or not completing their doctoral degree). However, Lovitts [23] believes that a combination of different characteristics, not an individual characteristic, impacts the student's outcome.

Lovitts [3], Cassuto [5], Willis et al. [7] and Bates [19] feel there is a possibility the higher education institution is the cause for the low doctoral student completion rate. Lovitts [3] believes "the causes of attrition are deeply embedded in the organizational culture of graduate school and the structure and process of graduate education".
Lovitts' [3] study stemmed from her “own unhappy experiences as a graduate student and departure from not one but two doctoral programs". She wrote:

I knew my experience was not unique, that about $50 \%$ of those who start PhD programs leave without a degree, yet we are isolated from one another. There were no support groups, no networks. No one cares about us. We were outcasts [3].

Furthermore, "the culture of graduate school, Lovitts [3] says, cultivates a 'pluralistic ignorance' in which everyone involved - deans, faculty members, students themselves - tend to blame the departing students for leaving" (as cited in Cassuto [5]). Lovitts [3] stated, "it is not the background characteristic students bring with them to the university that affect their persistence outcomes; it is what happens to them after they arrive". Research conducted by Willis et al. [7] found "all five dropping out participants reported problematic relationship with their dissertation chair. Neglected, and in one case harassed" [7]. In addition, The Ph.D. Completion Project identified six institutional and program characteristics (i.e., financial support, research mode of the field/doctoral student's discipline, mentoring, selection, processes and procedures and, program environment) that affect doctoral student outcomes [19].

Rockinson-Szapkiw et al. [8] found 12 factors on "both the student level and the institutional level that contribute to students' choice to leave doctoral programs" [8]. They identified the dissertation as the number one reason why students do not complete their degree. In addition, in no particular order, student feels isolation and program/degree depersonalization, family commitments, not making the doctoral program the top priority, disconnect with faculty and students, "Doctoral students are often selected due to their dedication to precise work and a drive for excellence. Unfortunately, students with these traits are more likely to become unsatisfied and easily frustrated with poor program organization" [8], stress and losses of motivation, not knowing school regulations, guidelines and program structure ambiguity, program inflexibility, program is not a walk in the park, and hardship (e.g., financial or personal) are the remaining factors on "both the student level and the institutional level that contribute to students' choice to leave doctoral programs" [8]. Furthermore, Rockinson-Szapkiw et al. [8] found six factors doctoral students need to be successful and complete their work on the degree. The six factors are "a sense of belonging; a motivation to accomplish; academic integration; autonomy and opportunity for choice; the ability to overcome adversity and personal sacrifice; and financial survival" [8]. 


\section{Findings and Discussion}

\subsection{Research Question 1}

The research findings of this study identify employment and financial factors as the principal reasons for non-completion of the original doctoral degree. For the employment factor, Participant \#1 received a promotion that caused him to relocate. He stated, "I just physically couldn't be there for the classes anymore." Participant \#1's response raised another question: Did the student reach out to Institution A to explain his personal situation (i.e., the promotion and relocating) and ask for help? Participant \#1 stated the following:

I didn't even bother reaching out to them because they were so, my, my feeling was they were so kind of set in their ways, you know, old fashion type of school that they just. No, I never reached out to them. I just, I didn't think it would make any difference. ... it wasn't a real, real friendly or warm environment at all. ... I guess I'll be quite honest with you. A matter of fact that the attitude they gave off was that, they almost didn't want you to finish. I think their attitude was, you know, who you know, who we can weed out of the program.

Participant \#2 had "so many [work] responsibilities, so many commitments and deadlines". Participant \#2's response raised another question: Did the student reach out to Institution B to explain his personal situation (i.e., work responsibilities) and ask for help? Participant \#2 stated, "No, I probably could have asked for a leave of absence from the program but to me that seemed like acknowledging failure." Lastly, Participant \#3 believed his personal finances was the main factor for not completing his original program. Participant \#3's response raised another question: Did the student reach out to Institution $\mathrm{C}$ to explain his personal situation (i.e., lacking funds to complete) and ask for help? Participant \#3 stated, "I didn't reach out. Once they told me that GMercyU's program was online, that was attractive to me".

In addition, there were additional factors that prevented the doctoral-non-completers to leave their prior institution. The additional factors were the program environment, program being disorganized, perception that not all of the required courses were in line with the degree, unsupportive environment, lack of dissertation coursework, and job stressors. Furthermore, ROI (i.e., "wasn't sure that all of this effort was going to pay off") was an additional factor for two of the three participants to not complete their original degree. Figure 2, Correlation Between Research Participants Factors for Leaving their Original Doctoral Program and the 12 Factors, provides a visual illustration of how the participants' answers in this research compares with Rockinson-
Szapkiw et al. [8] 12 factors "on both the student level and the institutional level that contribute to students' choice to leave doctoral programs". The participants' principal factors, for leaving their prior doctoral program, are in bold and the additional factors are in regular text.

\begin{tabular}{|c|c|c|}
\hline $\begin{array}{l}\text { Participant's } \\
\text { answers for } \\
\text { leaving their } \\
\text { original doctoral } \\
\text { program }\end{array}$ & & $\begin{array}{l}\text { Rockinson-Szapkiw et al. }[8] 12 \\
\text { factors "on both the student level } \\
\text { and the institutional level that } \\
\text { contribute to students' choice to } \\
\text { leave doctoral programs" }\end{array}$ \\
\hline Employment & $\rightarrow$ & Family commitments \\
\hline Relocation & $\rightarrow$ & Program inflexibility \\
\hline $\begin{array}{l}\text { Financial } \\
\text { factors }\end{array}$ & $\rightarrow$ & Hardship \\
\hline $\begin{array}{l}\text { Program } \\
\text { environment }\end{array}$ & $\rightarrow$ & $\begin{array}{l}\text { Disconnect with faculty and } \\
\text { students }\end{array}$ \\
\hline $\begin{array}{l}\text { Unsupportive } \\
\text { environment }\end{array}$ & $\begin{array}{l}\rightarrow \\
\rightarrow\end{array}$ & $\begin{array}{l}\text { Feeling isolated } \\
\text { Disconnect with faculty and } \\
\text { students }\end{array}$ \\
\hline $\begin{array}{l}\text { Program being } \\
\text { disorganized }\end{array}$ & $\rightarrow$ & $\begin{array}{l}\text { Selected for "dedication to precise } \\
\text { work and a drive for excellence" } \\
\text { but became "unsatisfied and easily } \\
\text { frustrated with poor program } \\
\text { organization" }\end{array}$ \\
\hline $\begin{array}{l}\text { Perception not all } \\
\text { of the required } \\
\text { courses were in } \\
\text { line with degree }\end{array}$ & $\rightarrow$ & $\begin{array}{l}\text { Selected for "dedication to precise } \\
\text { work and a drive for excellence" } \\
\text { but became "unsatisfied and easily } \\
\text { frustrated with poor program } \\
\text { organization" }\end{array}$ \\
\hline $\begin{array}{l}\text { Lack of } \\
\text { dissertation } \\
\text { coursework }\end{array}$ & $\rightarrow$ & $\begin{array}{l}\text { Dissertation (according the } \\
\text { research is the number one reason) } \\
\text { Not knowing school regulations, } \\
\text { guidelines and program structure } \\
\text { ambiguity }\end{array}$ \\
\hline \multirow[t]{2}{*}{ Job stressors } & $\begin{array}{l}\rightarrow \\
\rightarrow\end{array}$ & $\begin{array}{l}\text { Family commitments } \\
\text { Stress and losses motivation }\end{array}$ \\
\hline & $\begin{array}{l}X \\
X \\
X\end{array}$ & $\begin{array}{l}\text { Program/degree depersonalization } \\
\text { Making the doctoral program the } \\
\text { top priority } \\
\text { Program is not a walk in the park }\end{array}$ \\
\hline
\end{tabular}

Figure 2. Correlation Between Research Participants Factors for Leaving their original Doctoral Program and the 12 Factors

Employment impacted family commitments. In addition, relocating needed a program to be flexible. A financial factor was a hardship because one did not have funding or able to make payment for courses. An unfriendly program environment resulted in a disconnect with faculty and students. If the program or higher educational institution has an unsupportive environment the student could have a disconnect with faculty and students followed by the student feeling isolated. One participant stated, "they almost didn't want you to finish" was the attitude they received from their prior doctoral program. Thus, one could strongly argue, the projection a higher educational institution gives matters. In addition, a program that was disorganized led a student to become unsatisfied. Furthermore, a student had the perception not all of the required courses were in line with the degree and the student felt the program was 
disorganized and, then again, the student became unsatisfied. Furthermore, a lack of dissertation coursework did not assist the student in completing their dissertation and knowing the school regulations, guidelines and program structure. Lastly, job stressors impacted family commitments and created stress and loss of motivation. However, three (i.e., program/degree depersonalization; making the doctoral program the top priority; and program is not a walk in the park) of Rockinson-Szapkiw et al. [8] 12 factors, were discussed during the interview, but the three factors were not any of the participant's factors for leaving their original program. However, even though none of the students stated the dissertation was a factor for them leaving their prior institution, two out of the three participants completed all their course work up to the dissertation. Therefore, one could argue, this supports Rockinson-Szapkiw et al. [8] belief that the dissertation is a reason why students do not complete their doctoral degree. Furthermore, Participants \#1's comment (i.e., "I didn't think it [reaching out] would make any difference. ... it [Institution A] wasn't a real, real friendly or warm environment at all. ... the attitude they gave off was that, they almost didn't want you to finish") reinforces two of the six institutional and program characteristics (i.e., mentoring, program environment) that The Ph.D. Completion Project identified that affect doctoral student outcomes [19] and Cassuto's [5] belief the program's culture is a factor in whether the students stays in the program or leaves.

\subsection{Research Question 2}

According to the participants the main factors that led them to complete the ABD Completion Program at GMercyU were the program being on-line and highly flexible; restructuring lifestyle (i.e., retired); and being in a different financial situation. Furthermore, additional factors that led the participants to complete the ABD Completion Program at GMercyU were the cohort model, connecting with other students, supportive dissertation chair, flexibility with program requirements, and course-structure when writing dissertation. Participant \#1 felt the cohort model and connection with other students was an additional factor for helping him complete the ABD program at GMercyU. Participant \#1 stated the following:

I liked the cohort model. I like, matter of fact, I'm still in touch with a couple of the guys. The other guy just in my cohort, just finished his defense a couple of weeks ago. ... felt like you were more in touch with the students even though it was all remote and it was online, the way GMercyU set it up.
Participant \#2 felt his dissertation chair was more supportive at GMercyU. Participant \#2 stated, "my dissertation chair the second time was very different. The second one wanted to be supportive. But, the first one didn't seem to have that as motivation." In addition, Participant \#2 felt the ABD program was the right fit and design. He liked the fact that the ABD program had him complete his courses and his dissertation at the same time. He stated, "I liked it. It worked really well for me. I can't say it's the right fit or the right design for everybody. But, it certainly worked well for me." Furthermore, Participant \#2 stated GMercyU was flexible with their program requirements. He was not able to attend the international in-person residency course. Therefore, his program requirements were adjusted to accommodate his needs. He completed a three- week intense international education course on-line. Participant \#2 stated the following:

I had a medical procedure in May, so I couldn't travel. But I could take a [on-line] course ... There were eight or nine of us that were [in the on-line course]. ... it was an intense three weeks, ... So I just hung out in my apartment and completed the course in that three weeks because I'd had a hernia surgery so I wasn't going anywhere, except working on that stuff.

Figure 3, Correlation Between Research Participants Factors for Completing GMercyU's ABD Completion Program and the Six Factors, provides a visual illustration of how the participants' answers in this research compares with RockinsonSzapkiw et al. [8] six factors doctoral students need to be successful and complete their work on the degree. The participants' principal factors, that led the participants in completing the ABD Completion Program, are in bold and the additional factors are in regular text.

The on-line and highly flexible program allowed the doctoral students to have autonomy and opportunity for choice. Whereas restructuring lifestyle (i.e., retired) gave the student the ability to overcome adversity and personal sacrifice. In addition, being in a different financial situation allowed a student to have financial survival. The cohort model gave the doctoral students a sense of belonging, and a motivation to accomplish. Connecting with other students gave the students a sense of belonging and a motivation to accomplish. A supportive dissertation chair gave the doctoral student a sense of belonging, a motivation to accomplish, academic integration, autonomy and opportunity for choice, and the ability to overcome adversity and personal sacrifice. Furthermore, flexible with program requirements gave the student a sense of belonging, a motivation to accomplish, autonomy and opportunity for choice, and the ability 
to overcome adversity. In addition, course-structure when writing dissertation gave the doctoral student a sense of belonging and a motivation to accomplish. All of Rockinson-Szapkiw et al. [8] six factors, that doctoral students need to be successful and complete their work on the degree, were found at GMercyU's ABD Completion Program, according to the participants in this research study.

\begin{tabular}{|c|c|c|}
\hline $\begin{array}{l}\text { Participant's answers } \\
\text { for completing } \\
\text { GMercyU's ABD } \\
\text { Completion Program }\end{array}$ & & $\begin{array}{l}\text { Rockinson-Szapkiw et al. [8] } \\
\text { Six factors doctoral students } \\
\text { need to be successful and } \\
\text { complete their work on the } \\
\text { degree }\end{array}$ \\
\hline $\begin{array}{l}\text { On-line and highly } \\
\text { flexible }\end{array}$ & $\rightarrow$ & $\begin{array}{l}\text { Autonomy and opportunity } \\
\text { for choice }\end{array}$ \\
\hline $\begin{array}{l}\text { Restructuring } \\
\text { lifestyle (i.e., retired) }\end{array}$ & $\rightarrow$ & $\begin{array}{l}\text { The ability to overcome } \\
\text { adversity and personal } \\
\text { sacrifice }\end{array}$ \\
\hline $\begin{array}{l}\text { Different financial } \\
\text { situation }\end{array}$ & $\rightarrow$ & Financial survival \\
\hline Cohort model & $\vec{\rightarrow}$ & $\begin{array}{l}\text { A sense of belonging } \\
\text { A motivation to accomplish }\end{array}$ \\
\hline $\begin{array}{l}\text { Connecting with other } \\
\text { students }\end{array}$ & $\vec{\rightarrow}$ & $\begin{array}{l}\text { A sense of belonging } \\
\text { A motivation to accomplish }\end{array}$ \\
\hline $\begin{array}{l}\text { Supportive dissertation } \\
\text { chair }\end{array}$ & $\begin{array}{l}\rightarrow \\
\rightarrow \\
\rightarrow \\
\rightarrow \\
\rightarrow\end{array}$ & $\begin{array}{l}\text { A sense of belonging } \\
\text { A motivation to accomplish } \\
\text { Academic integration } \\
\text { Autonomy and opportunity } \\
\text { for choice } \\
\text { The ability to overcome } \\
\text { adversity and personal } \\
\text { sacrifice. }\end{array}$ \\
\hline $\begin{array}{l}\text { Flexible with program } \\
\text { requirements }\end{array}$ & $\begin{array}{l}\rightarrow \\
\rightarrow \\
\rightarrow \\
\rightarrow\end{array}$ & $\begin{array}{l}\text { A sense of belonging } \\
\text { A motivation to accomplish } \\
\text { Autonomy and opportunity } \\
\text { for choice } \\
\text { The ability to overcome } \\
\text { adversity }\end{array}$ \\
\hline $\begin{array}{l}\text { Course-structure when } \\
\text { writing dissertation }\end{array}$ & $\begin{array}{l}\rightarrow \\
\rightarrow\end{array}$ & $\begin{array}{l}\text { A sense of belonging } \\
\text { A motivation to accomplish }\end{array}$ \\
\hline
\end{tabular}

Figure 3. Correlation Between Research Participants Factors for Completing GMercyU's ABD Completion Program and the Six Factors

One could argue, GMercyU's simultaneous doctoral course sequence, which includes a dissertation course-structure (see Figure 1), assisted all of the doctoral students in completing the ABD Completion Program. Thus, the Dissertation Advisement courses counter-reacts RockinsonSzapkiw et al. [8] number one reason why students do not complete their degree - the dissertation. In addition, a cohort model also stops students from feeling isolated and having a disconnect with faculty and students. Moreover, GMercyU's program was flexible as illustrated with Participant \#2's statement, "I couldn't travel", about not being able to attend the international in-person residency; therefore, Participant \#2 took an online course. In addition, according to Participant \#2's statement, “eight or nine" other students benefited from the program flexibility also. Furthermore, GMercyU provides program/degree personalization, because the ABD
Completion Program director evaluates each doctoral-non-completer-student's transcript in order for their individual learning plan. Therefore, one could argue, when GMercyU designed their ABD Completion Program they considered and understood Rockinson-Szapkiw et al. [8] 12 factors "on both the student level and the institutional level that contribute to students' choice to leave doctoral programs"; the six institutional and program characteristics identified in The Ph.D. Completion Project [19] and Cassuto's [5] belief the program's culture is a factor in whether the students stays in the program or leaves. One could argue, when GMercyU designed their ABD Completion program they counter-reacted to many of the reasons why doctoral students leave their programs, in order to assist doctoral students with completing their doctoral degree.

\section{Conclusion}

Why do some doctoral students complete their degrees and others do not? This research study investigated: (1) What are the principal factors that influenced doctoral-non-completer-students to leave their original doctoral program without completing the degree? The research findings of this study identify employment and financial factors as the principal reasons for non-completion of a doctoral degree. The additional factors that led two of the three participants to become non-completers were "wasn't sure that all of this effort was going to pay off" (i.e., ROI) were an additional factor for two of the three participants to not complete their original degree. Additional factors that led at least one of the participants to become a non-completer were the institutional and program environment, including not looking out for one of the participant's best interest as a doctoral student; and job stressors. In addition, the institution's environment (i.e., unfriendly and the attitude "they almost didn't want you to finish"), lack of program organization, and the perception that the required courses did not fit the program objectives. However, unfortunately, none of the participants reached out to their original institution to explain their personal situation and ask if the institution could work with them. Therefore, one could argue, this supports "trickle out" effect [5] theory and, more importantly, Lovitts [3] belief that doctoral attrition rate is invisible to higher education institution's staff because of how the doctoral-non-completer-students depart from the higher education institution. Why did the doctoral-non-completer-students just leave without attempting to reach out to their prior institutions? Did the prior institution try to reach out to the students?

Furthermore, this research study also investigated: (2) What are the principal factors that influenced these prior doctoral-non-completer- 
students to actually complete their degree requirements in a different university's doctoral program? This study found an on-line and highly flexible program, making the doctoral program top priority, and being in a different financial situation were the principal factors for the doctoral-noncompleters to complete their doctoral degree in a different university's doctoral program. In addition, a cohort model, a connection with other students, more supportive dissertation chair, the fact that GMercyU's program utilized a simultaneous doctoral course sequence model, and GMercyU was flexible with their program requirements were additional factors that helped the participants to complete their doctoral degree at another higher education institution. One could argue, GMercyU carefully designed their ABD Completion program in order to assist doctoral students with completing their doctoral degree.

At the start of this research, the ABD Completion program was in its infancy stage and no females responded to be a participant for this research. Thus, this research only had three male participants. Therefore, further research might want to consider a larger and more diverse population in a few years. In addition, if the population size is large enough one could consider a quantitative research approach. In addition, this research only had participants whose prior doctoral institutions were in the U.S. Therefore, further research should consider doctoral-noncompleters that attended international programs. At the conclusion of this research (three years later) there were three $\mathrm{ABD}$ completion programs in the U.S.

\section{References}

[1] Abiddin, N. Z., and Ismail, A. (2011). Attrition and Completion Issues in Postgraduate Studies for Student Development. International Review of Social Sciences and Humanities, 1(1), 15 - 29.

[2] Lovitts, B., and Nelson, C. (2000). The Hidden Crisis in Graduate Education: Attrition from Ph.D. Programs. Academe, 86(6), 44-50. doi:10.2307/40251951 (Access Date: 18 July 2021).

[3] Lovitts, B. E. (2001). Leaving the Ivory Tower: The Causes and Consequences of Departure from Doctoral Study. Lanhan, Maryland, United States of America: Rowman and Littlefield Publishers, Inc.

[4] Bowen, W. G., and Rudenstine, N. L. (1992). In Pursuit of the Ph.D. (1st ed.). Princeton, New Jersey, United States of America: Princeton University Press.

[5] Cassuto, L. (2013). Ph.D. Attrition: How Much Is Too Much? The Chronicle of Higher Education, (July 1). https://www.chronicle.com/article/PhD-Attrition-How-Mu ch-Is/140045 (Access Date: 05 July 2021).
[6] MacLeod, D. (2005). Study Reveals Low PhD Completion Rates. Retrieved from The Guardian | Higher Education, (January 10). https://www.theguardian.com/ed ucation/2005/jan/11/highereducation.uk1 (Access Date: 05 July 2021)

[7] Willis, B., and Carmichael, K. D. (2011, January 01). The Lived Experience of Late-Stage Doctoral Student Attrition in Counselor Education. The Qualitative Report, 16(01), 192 - 207. https://nsuworks.nova.edu/cgi/viewcon tent.cgi? article $=1046$ andcontext=tqr (Access Date: 18 July 2021).

[8] Rockinson-Szapkiw, A. J., Spaulding, L. S., and Bade, B. (2014). Completion of Educational Doctorates: How Universities Can Foster Persistence. Retrieved from International Journal of Doctoral Studies, 9, 293 - 308. http://ijds.org/Volume9/IJDSv9p293-308Rockinson0607.p df (Access Date: 05 July 2021).

[9] Nyquist, J. D., and Woodford, B. J. (2000). Reenvisioning the Ph.D.: What Concerns Do We Have? Retrieved from University of Washington, (April 13). https://depts.washington.edu/envision/resources/Concerns Brief.pdf (Access Date: 05 July 2021).

[10] D'Andrea, L. M. (2002). Obstacles to Completion of the Doctoral Degree in Colleges of Education: The Professors' Perspective. Retrieved from Educational Research Quarterly, 42 - 58, (March 01). http://web.b. ebscohost.com.mylibrary.wilmu.edu/ehost/pdfviewer/pdfvi ewer?vid=1 andsid=542be46b-fcfe-430c-b344-0191ba9707 b5\%40pdc-v-sessmgr01 (Access Date: 05 July 2021).

[11] Freedman, J. (2014). Student Loans Are A Drag On The Economy And Society. Retrieved from Forbes, (February 11). https://www.forbes.com/sites/joshfreedman /2014/02/11/student-loans-are-a-big-drag-on-the-economyand-society/\#42aa6ca74bc1 (Access Date: 05 July 2021).

[12] Cooper, P. (2018, August 09). Why Do College Dropouts Fail To Repay Their Student Loans? Retrieved from Forbes, (August 09). https://www.forbes.com/sites/ prestoncooper2/2018/08/09/why-do-college-dropouts-failto-repay-their-student-loans/-3614a2d24443 (Access Date: 05 July 2021).

[13] Bogle, S. (2017, November 08). What Is a Terminal Degree? Retrieved from Southern New Hampshire University: https://www.snhu.edu/about- us/newsroom/20 17/11/terminal-degrees (Access Date: 18 July, 2021).

[14] Wolken, D. J. (n.d.). The American University and "The German Model" - A Transnational History. Syracuse University: https://mrperez.expressions.syr.edu/ immigration/education/wolken/ (Access Date: 18 July, 2021).

[15] Maloney, E. J. (2019, February 20). Learning Innovation: Ph.D. or Ed.D.? Retrieved from Insider Higher ED:https://www.insidehighered.com/digital-learning/blog s/technology-and-learning/what-should-be-terminal-degree -our-new- field-learning (Access Date: 18 July, 2021).

[16] Kehm, B. M. (2005, September) Forces and Forms of Change. Doctoral Education in Germany within the 
European Framework. Paper presented at the international conference on 'Forces and Forms of Change in Doctoral Education Internationally' organized by CIRGE, University of Washington, August

[17] Graduate School I Initiatives in Doctoral Education and Student Support. (2019). Brown University: https://www.brown.edu/academics/gradschool/about/initiat ives-doctoral-education-and-student-support (Access Date: 18 July 2021).

[18] Nova Southeastern University, "ED.D. in Higher Education Leadership 2018" (2018). Fischler Postgraduate Course Catalogs. 424. https://nsuworks.nova.edu/cgi/view content.cgi?article $=1435$ andcontext=abe_pgcoursecatalogs (Access Date: 18 July 2021).

[19] Bates, M. (2011, July 26). The Ph.D. Completion Project. Retrieved from American Association For The Advancement of Science: https://www.aaas.org/blog/steme du/phd-completion-project (Access Date: 18 July 2021).

[20] Elgar, F. (2002). PhD Degree Completion in Canadian Universities: Final Report. Halifax: Graduate Students Association of Canada. https://www.researchgate.net/pub lication/236595361_PhD_Degree_Completion_in_Canadia n_Universities_Final_Re port/download (Access Date: 18 July, 2021).

[21] Patterson, T. (2016, July 06). Why Do So Many Graduate Students Quit? Universities themselves may be contributing to burnout. Retrieved from The Atlantic | Education: https://www.theatlantic.com/education/archive /2016/07/why-do-so-many-graduate-students-quit/490094/ (Access Date: 18 July 2021).

[22] Chenevix-Trench, G. (2006, May 11). What makes a good PhD student? Nature, 441, 252. https://www.nature .com/articles/nj7090-252b (Access Date: 18 July, 2021).

[23] Lovitts, B. E. (2008, May/June). The Transition to Independent Research: Who Makes It, Who Doesn't, and Why. The Journal of Higher Education, 79(3), 296 - 325. https://www.jstor.org/stable/25144670 (Access Date: 18 July, 2021). 